\title{
Clinical, pathological, and immunohistochemistry characterization of toxoplasmosis in dogs with distemper in the semiarid region of Paraíba, Brazil
}

\author{
Caracterização clínica, patológica e imuno-histoquímica da \\ toxoplasmose em cães com cinomose no semiárido da Paraíba, Brasil
}

\author{
Maria Talita Soares Frade ${ }^{1 *}$; Lisanka Ângelo Maia ${ }^{1}$; \\ Rachel Livingstone Felizola Soares Andrade'; Rodrigo Cruz Alves²; \\ Elise Miyuki Yamasaki³; Rinaldo Aparecido Mota ${ }^{4}$; \\ Antônio Flávio Medeiros Dantas ${ }^{5}$
}

\begin{abstract}
The objective of this study was to describe the clinical, pathological, and immunohistochemistry characteristics of five cases of toxoplasmosis, an infection often associated with distemper in dogs. From January 2000 to December 2012, a retrospective study was performed analyzed dogs with distemper in the semiarid region of Paraíba. We evaluated this sample to focus on individuals who presented with concomitant structures in protozoa characteristics, and performed immunohistochemistry (IHC) tests using polyclonal anti-Toxoplasma gondii antibody. In all cases, the clinical signs were similar including digestive changes, as well as respiratory, neurological, and ocular lesions, suggesting an infection of canine distemper virus. The diagnosis of distemper was confirmed on histopathological analysis depending on the presence of intranuclear and intracytoplasmic eosinophilic inclusion bodies in different tissues. Histopathological examination also revealed the characteristic presence of parasitic cysts $T$. gondii in the brain in four cases, and in the lung in one case. The brain cysts were associated with multifocal areas of malacia and lung there was alveolar septa thickening due to infiltration of macrophages, lymphocytes, and plasma cells, with moderate proliferation of type II pneumocytes and coalescing multifocal areas of necrosis. These cysts are characterized by round and strongly basophilic structures, measuring approximately 5 to $70 \mu \mathrm{m}$, delimited by thin wall, stained by hematoxylin and eosin, and immunomarked as brown by immunohistochemistry (IHC) using the chromogen DAB. The diagnosis of toxoplasmosis associated with infection by canine distemper virus in the five case studied was based on microscopic findings and confirmed by immunohistochemistry. Toxoplasmosis should be included in the differential diagnosis of dogs with severe progressive systemic signs, especially when respiratory and neurological involvement is suspected.
\end{abstract}

Key words: Dog, distemper, toxoplasmosis, immunohistochemistry

\footnotetext{
${ }^{1}$ Discentes no Programa de Pós-Graduação em Medicina Veterinária, PPGMV, Hospital Veterinário, HV, Centro de Saúde e Tecnologia Rural, CSTR, Universidade Federal de Campina Grande, UFCG, Campus de Patos, Patos, PB, Brasil. E-mail: talita frade@hotmail.com; lisankavet@hotmail.com; rachellvet@gmail.com

2 Residente em Patologia Animal, HV, CSTR, UFCG, Campus de Patos, Patos, PB, Brasil. E-mail: rodrigo_cruz90@live.com

${ }_{3}^{3}$ Discente, Programa de Pós-Graduação em Ciência Veterinária, Laboratório de Doenças Infectocontagiosas dos Animais Domésticos, Dept ${ }^{\circ}$ de Medicina Veterinária, DMV, Universidade Federal Rural de Pernambuco, UFRPE, Recife, PE, Brasil. E-mail: elise_my@msn.com

${ }^{4}$ Prof., Programa de Pós-Graduação em Ciência Veterinária, Laboratório de Doenças Infectocontagiosas dos Animais Domésticos, DMV, UFRPE, Recife, PE, Brasil. E-mail: rinaldo.mota@hotmail.com

5 Prof., PPGMV, HV, CSTR, UFCG, Campus de Patos, Patos, PB, Brasil. E-mail: dantas.af@uol.com.br

* Author for correspondence
} 


\title{
Resumo
}

\begin{abstract}
Objetivou-se com este trabalho descrever as características clínicas, patológicas e imuno-histoquímica de cinco casos de toxoplasmose associados à cinomose em cães no semiárido da Paraíba. Para isso, foi realizado um estudo retrospectivo durante o período de janeiro de 2000 a dezembro de 2012, sendo identificados e selecionados os casos de cães com cinomose. Destes, foram avaliados os que apresentavam concomitantemente estruturas características de protozoários e realizada a imunohistoquímica (IHQ) com anticorpo policlonal anti-Toxoplasma gondii. Em todos os casos os sinais clínicos foram semelhantes e sugestivos de infecção pelo vírus da cinomose canina, variando de alterações digestivas, respiratórias, neurológicas e lesões oculares. O diagnóstico de cinomose foi confirmado na histopatologia através da presença de corpúsculos de inclusões virais eosinofílicos intranucleares e intracitoplasmáticos em diferentes tecidos. O exame histopatológico revelou ainda a presença dos cistos parasitários característicos de T. gondii no encéfalo em quatro casos e no pulmão em um caso. No encéfalo os cistos estavam associados a áreas multifocais de malacia e no pulmão havia espessamento dos septos alveolares por infiltrado de macrófagos, plasmócitos e linfócitos, com proliferação moderada de pneumócitos tipo II e áreas multifocais a coalescentes de necrose. Esses cistos caracterizaram-se por estruturas arredondadas fortemente basofílicas medindo aproximadamente de 5 a $70 \mu \mathrm{m}$, delimitadas por uma fina parede pela hematoxilina e eosina e na IHQ foram fortemente imunomarcados em marrom para T. gondii. O diagnóstico de toxoplasmose associado à infecção pelo vírus da cinomose nos cinco casos estudados foi baseado nos achados microscópicos e confirmado através da imuno-histoquímica. A toxoplasmose deve ser incluída no diagnóstico diferencial de cães com sinais sistêmicos progressivos severos, principalmente quando há envolvimento respiratório e neurológico.
\end{abstract}

Palavras-chave: Cão, cinomose, toxoplasmose, imuno-histoquímica

\section{Introduction}

Toxoplasma gondii protozoan infections are widely prevalent in humans and animals. These infections affect several species of mammals and birds and are found on all continents (DUBEY, 2004; FIALHO et al., 2009). In Brazil, serological studies show a high prevalence of this disease in the canine populations in the states of Mato Grosso (SANTOS et al., 2009), Paraná (GIRALDI et al., 2002), Pará (VALADAS et al., 2010), Paraíba (AZEVEDO et al., 2005), and São Paulo (BRITO et al., 2002). Infection rates vary by state, measured at $88.5 \%$, $82.5 \%, 69.9 \%, 45.1 \%, 32.5 \%$ of the populations, respectively.

The dog has epidemiological importance, since it acts as an infection sentinel, and can determine a risk factor for public health by the mechanical transmission of $T$. gondii for humans (LINDSAY et al., 1997; ULLMANN et al., 2008).

Immunity does not eliminate an infection established by $T$. gondii, and tissue cysts persist for several years after an acute infection. However, in immunocompromised individuals, the infection can be reactivated by the dissemination conversion of tachyzoites and bradyzoites in tissue (DUBEY, 2004), generally associated with canine distemper virus (AGUIAR et al., 2012; MORETTI et al., 2002; SILVA et al., 2007).

This study describes five cases of toxoplasmosis associated with distemper in dogs in the semiarid region of Paraíba and their clinical, pathological, and immunohistochemical characteristics.

\section{Material and Methods}

We reviewed the necropsy records of dogs diagnosed with canine distemper in the Animal Pathology Laboratory of the Federal University of Campina Grande, Campus of Patos, Paraíba, between January 2000 and December 2012.

The cases that had concurrently cystic structures showing intralesional characteristics of protozoa morphologically compatible with $T$. gondii were separated. These cases were assessed via the clinical 
signs, as well as macroscopic and microscopic changes described in necropsy reports.

For confirmation, immunohistochemistry (IHC) was performed using the anti- $T$. gondii antibody with tissues embedded in paraffin blocks. The criterion for selection of the blocks was the presence of intralesional protozoal characteristic structures in tissue stained with hematoxylin and eosin.

We cut $3-\mu \mathrm{m}$ sections of the tissue in paraffin blocks and applied them to slides (ImmunoSlideEasyPath). Then, the sections were de-paraffinized and rehydrated. The endogenous peroxidase was blocked by incubating the tissues twice for 10 minutes in a $3 \%$ hydrogen peroxide solution in distilled water and subsequently washing them in distilled water. Antigen retrieval was performed using citrate buffer ( $\mathrm{pH}$ 6.0) in a microwave oven for 10 minutes at full power. Soon after, the slides were cooled for 10 minutes in a cold-water bath. To decrease non-specific binding (background), the sections were treated for 30 minutes with 5\% powdered and skimmed milk (Molico) in distilled water. The sections were incubated in a humid chamber at $37^{\circ} \mathrm{C}$ for 60 minutes with the primary polyclonal antibody anti- $T$. gondii produced in rabbit diluted to 1:100 in antibody diluent (PBS $\mathrm{pH} 7.4$, EasyPath). The sections were then treated with biotinylated secondary reagent followed by streptavidin-peroxidase (LSAB+SystemHRP, Dako) and incubated at room temperature for 30 minutes in a humid chamber; they were then marked by adding the chromogen 3,3'-diaminobenzidine (DAB; Dako) for 2 minutes, followed by inactivation with water. The sections were washed and lightly counterstained with Harris hematoxylin, and then washed in running water for 10 minutes, dehydrated in alcohol graduations, clarified in xylol, and mounted with coverslips and Entellan. As a negative control, the same sections were used, replacing the primary antibody with a PBST.

\section{Results}

From January 2000 to December 2012, 1022 dogs were necropsied, and 132 (12.9\%) were diagnosed as cases of canine distemper. Of those, five cases of distemper were associated with characteristic parasitic cysts of $T$. gondii intralesional (3.7\%), with four cases in the brain and one in the lung.

Clinical signs were similar in all cases and also suggestive of infection by canine distemper virus. These signs included digestive disorders, as well as respiratory, neurological, and ocular lesions (Table 1).

Table 1. Epidemiology and clinical of toxoplasmosis cases associated with distemper in dogs in the semiarid region of Paraíba during the period from January 2000 to December 2012.

\begin{tabular}{|c|c|c|}
\hline Case & Breed/Sex/Age & Clinical signs \\
\hline 1 & $\begin{array}{c}\text { Belgian shepherd, Female, } \\
5 \text { months }\end{array}$ & Eye discharge, salivation, diarrhea, myoclonus \\
\hline 2 & $\begin{array}{c}\text { Mixed breed, Male, } \\
7 \text { years }\end{array}$ & Anorexia, cough, unsteady walk, tenesmus, prostration, strabismus, myoclonus \\
\hline 3 & $\begin{array}{c}\text { Mixed breed, Female, } \\
8 \text { years }\end{array}$ & Eye discharge, diarrhea, myoclonus \\
\hline 4 & $\begin{array}{c}\text { Pinscher, Female, } \\
3,7 \text { years }\end{array}$ & Fever, eye and nasal discharge, diarrhea, pulmonary rales, circling \\
\hline 5 & $\begin{array}{l}\text { Mixed breed, Male, } \\
6 \text { months }\end{array}$ & Anorexia, eye and nasal discharge, salivation, vocalization, myoclonus \\
\hline
\end{tabular}


The five dogs had a clinical diagnosis of distemper, confirmed by presence of bodies of eosinophilic intranuclear and intracytoplasmic viral inclusion in different tissues on histopathological analysis, which also revealed the presence of characteristic parasitic cysts of $T$. gondii in the brain in cases 1, 2, 3 and 4, and only in the lung in case 5 .

Microscopically in the brain, the lesions were characterized by multifocal areas of malacia associated with rounded, strongly basophilic structures, measuring approximately 5 to $70 \mu \mathrm{m}$, and containing a number of basophilic structures corresponding to bradyzoites delimited by a thin wall, all T. gondii characteristics (Figure 1A). Encircling these areas were mononuclear cell infiltrates composed predominantly of lymphocytes, plasma cells, macrophages and rare neutrophils. In two cases, the lesions were seen in the cortex and cerebellum (cases 1 and 2). In case 3, the lesions were restricted to the cerebellar peduncle. In case 4, the lesion was present in the frontal cortex, basal ganglia, thalamus, hippocampus, cerebellum and cerebellar peduncle, with loads of gitter cells and mononuclear leptomeningitis with infiltrate composed of macrophages, lymphocytes, and plasma cells.

Figure 1. Toxoplasmosis in dogs. A) Toxoplasmosis, cerebral cortex (gray matter). Observed are strongly basophilic round structures multiple delimited by a thin wall, cysts of Toxoplasma gondii features (arrows). HE. Obj. 40x. B) Toxoplasmosis, cerebellum. Positive immunomarking for $T$. gondii, the protozoan showing multiple exemplary in the granular and molecular layers (gray matter) (arrows). Immunohistochemistry, method of streptavidin-biotinperoxidase, counter-stained with Harris hematoxylin. Obj. 20x.

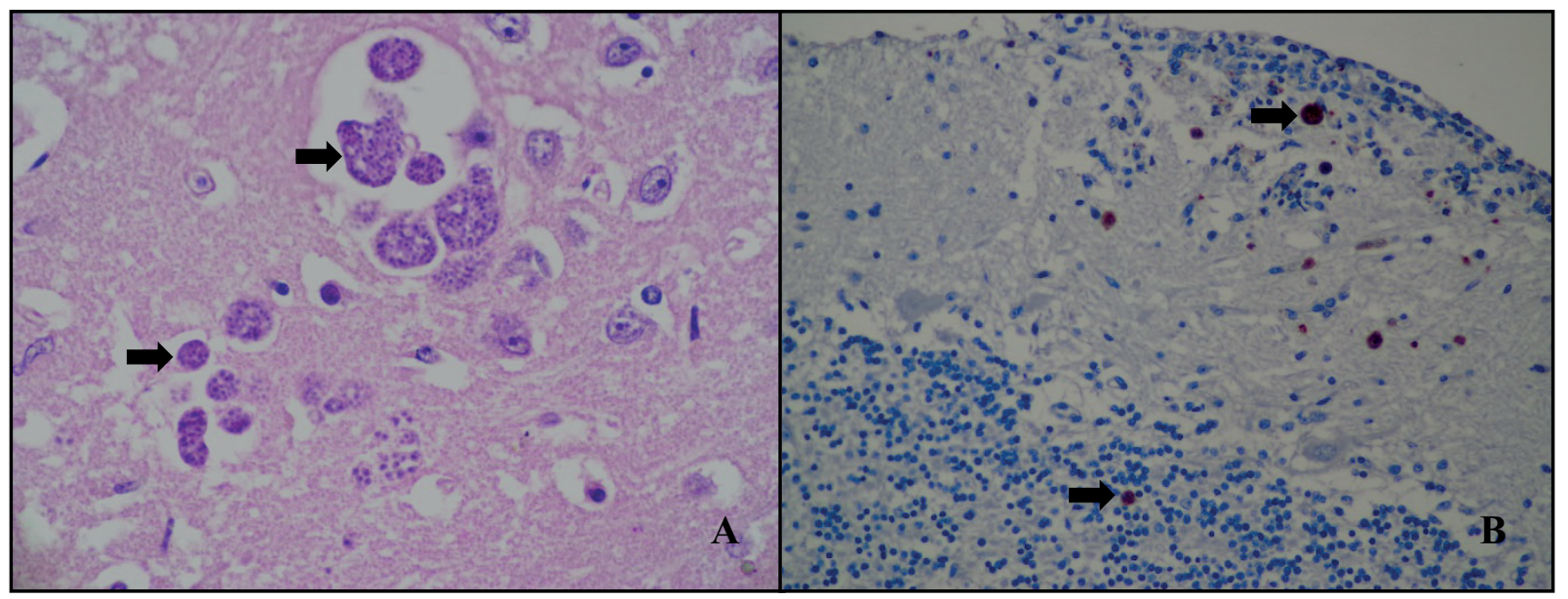

In case 5, the parasitic cysts were observed only in the lung. The lesion was characterized by thickening of the alveolar septa by mononuclear inflammatory infiltrate composed of macrophages, lymphocytes and plasma cells, with moderate proliferation of type II pneumocytes. Some had multifocal areas of necrosis coalescing with macrophages associated with $T$. gondii.
The histological findings compatible with distemper were characterized mainly by nonsuppurative encephalitis, demyelination and perivascular cuffing discrete, associated with intranuclear eosinophilic inclusion bodies in astrocytes, and intracytoplasmic and intranuclear in neurons and ependymal cells. Bodies of inclusion were also observed in extra-neural organs, such as 
the main and parietal cells of the gastric mucosa, the urothelium of the bladder and renal pelvis, the bronchus and bronchiole epithelium, and the epithelium of pancreatic acinar ducts and mononuclear cells.

In the five cases described here, immunohistochemical analysis of tissue that had cystic structures of Toxoplasma gondii showed marking positive (Figure 1B). Tachyzoites of characteristic structures were also observed in the cytoplasm of macrophages and endothelial cells of vessels.

\section{Discussion}

The diagnoses of toxoplasmosis associated with infection by canine distemper virus in the five case studies were based on microscopic findings and confirmed by immunohistochemistry.

Immunohistochemical analysis is important to differentiate $T$. gondii and Neospora caninum, since these protozoa are related and structurally similar. However, T. gondii is almost always associated with concomitant disease such as distemper in dogs, while the $N$. caninum appears to be a primary pathogen (MAXIE; YOUSSEF, 2007; LAPPIN, 2008; ZACHARY, 2013).

The clinical disease caused by .Toxoplasma gondii is rare. Similarly, it is widely known that severe clinical manifestation of toxoplasmosis occurs in immunosuppressed dogs (MORETTI et al., 2002). Additionally, there are reported cases of dogs with neurological disorders and the presence of $T$. gondii cysts in which lesions consistent with distemper were absent (GIRALDI et al., 2002).

Of the five cases of $T$. gondii associated with infection by canine distemper virus, four had involvement of the brain. These two conditions can occur concomitantly, and the nervous signs observed are indistinguishable. There are also high mortality rates associated with the simultaneous occurrence of these two agents in dogs (NELSON; COUTO, 1994; MORETTI et al., 2002).

Silva et al. (2007) demonstrated that toxoplasmosis was the most frequently observed co-infection in dogs with a neurological form of distemper, with a case of $T$. gondii in the brain, and four with visceral toxoplasmosis.

Information about contact frequencies with cats was not included in the original case history of the dogs. Despite the lack of data regarding the history of these animals, we suggest that the absence of immunoprophylaxis for distemper may have led to occurrence of the same, with consequent infection or reactivation of $T$. gondii being fatal. Important risk factors for the occurrence of toxoplasmosis in dogs are eating raw meat, free access to the street, food or water contaminated by feces, and/ or cohabitation with cats (MORETTI et al., 2002; DUBEY, 2004; AZEVEDO et al., 2005).

\section{Conclusions}

Toxoplasmosis should be included in the differential diagnosis of dogs with severe progressive systemic signs, especially with respiratory and neurological involvement, causing worsening of the clinical frame and disease progression to death.

The occurrence of fatal disease in immunosuppressed dogs in the home environment reinforces the importance for monitoring public health action to control this zoonosis.

\section{References}

AGUIAR, D. M.; AMUDE, A. M.; SANTOS, L. G. F.; RIBEIRO, M. G.; UENO, T. E. H.; MEGID, J.; PAES A. C.; ALFIERI, A. F.; ALFIERI, A. A.; GENNARI, S. M. Canine distemper virus and Toxoplasma gondii co-infection in dogs with neurological signs. Arquivo Brasileiro de Medicina Veterinária e Zootecnia, Belo Horizonte, v. 64, n. 1, p. 221-224, 2012. 
AZEVEDO, S. S.; BATISTA, C. S.; VASCONCELLOS, S. A.; AGUIAR, D. M.; RAGOZO, A. M.; RODRIGUES, A. A.; ALVES, C. J.; GENNARI, S. M. Seroepidemiology of Toxoplasma gondii and Neospora caninum in dogs from the state of Paraíba, Northeast region of Brazil. Research in Veterinary Science, Oxford, v. 79, n. 1, p. 51-56, 2005.

BRITO, A. F.; SOUZA, L. C.; SILVA, A. V.; LANGONI, $\mathrm{H}$. Epidemiological and serological aspects in canine toxoplasmosis in animals with nervous symptoms. Memórias do Instituto Oswaldo Cruz, Rio de Janeiro, v. 97, n. 1, p. 31-35, 2002.

DUBEY, J. P. Toxoplasmosis - a waterborne zoonosis. Veterinary Parasitology, Amsterdam, v. 126, n. 1-2, p. 57-72, 2004.

FIALHO, C. G.; TEIXEIRA, M. C.; ARAUJO, F. A. P. Toxoplasmose animal no Brasil. Acta Scientiae Veterinariae, Porto Alegre, v. 37, n. 1, p. 1-23, 2009.

GIRALDI, J. H.; BRACARENSE, A. P. F. R. L.; VIDOTTO, O.; TUDURY, E. A.; NAVARRO, I. T.; BATISTA, T. N. Sorologia e histopatologia de Toxoplasma gondii e Neospora caninum em cães portadores de distúrbios neurológicos. Semina: Ciências Agrárias, Londrina, v. 23, n. 1, p. 9-14, 2002.

LAPPIN, M. R. Infecções protozoárias e mistas. In: ETTINGER, J. S.; FELDMAN, E. C. Tratado de medicina interna veterinária: doenças do cão e do gato. 5. ed. Rio de Janeiro: Guanabara Koogan, 2008. p. 430439.

LINDSAY, D. S.; DUBEY, J. P.; BUTLER, J. M.; BLAGBURN, B. L. Mechanical transmission of Toxoplasma gondii oocysts by dog. Veterinary Parasitology, Amsterdam, v. 73, n. 1-2, p. 27-33, 1997.

MAXIE, M. G.; YOUSSEF, S. Nervous system. In: MAXIE, M. G. (Ed.). Jubb, Kennedy and Palmer's pathology of domestic animals. 5. ed. Philadelphia: Saunders Elsevier, 2007. v. 1. p. 281-457.
MORETTI, L. A.; UENO, T. E.; RIBEIRO, M. G.; AGUiAR, D. M.; PAES, A. C.; PEZERICO, S. B.; SILVA, A. V. Toxoplasmose em cães co-infectados com o vírus da cinomose. Semina: Ciências Agrárias, Londrina, v. 23, n. 1, p. 85-91, 2002.

NELSON, R. W.; COUTO, C. G. Encefalite/mielite/ meningite. In: Fundamentos de medicina interna de pequenos animais. Rio de Janeiro: Guanabara Koogan, 1994. p. 566-571.

SANTOS, T. R.; COSTA, A. J.; TONIOLlO, G. H.; LUVIZOTTO, M. C. R.; BENETTI, A. H.; SANTOS, R. R.; MATTA, D. H.; LOPES, W. D. Z.; OLIVEIRA, J. A.; OLIVEIRA, G. P. Prevalence of anti-Toxoplasma gondii antibodies in dairy cattle, dogs, and humans from the Jauru micro-region, Mato Grosso state, Brazil. Veterinary Parasitology, Amsterdam, v. 161, n. 3-4, p. 324-326, 2009.

SILVA, M. C.; FIGHERA, R. A.; BRUM, J. S.; GRAÇA, D. L.; KOMMERS, G. D.; IRIGOYEN, L. F.; BARROS, C. S. L. Aspectos clinicopatológicos de 620 casos neurológicos de cinomose em cães. Pesquisa Veterinária Brasileira, Seropédica, v. 27, n. 5, p. 215-220, 2007.

ULLMANN, L. S.; GUIMARÃES, F. F.; FORNAZARI, F.; TOMÉ, R. O.; CAMOSSI, L. G.; GRECA, H.; SILVA, R. C.; MENOZZI, B. D.; LANGONI, H. Ações de vigilância continuada, papel do cão como animal sentinela para toxoplasmose. Revista Brasileira Parasitologia Veterinária, Jaboticabal, v. 17, n. 1, p. 345 347, 2008.

VALADAS, S.; MINERVINO, A. H.; LIMA, V. M.; SOARES, R. M.; ORTOLANI, E. L.; GENNARI, S. M. Ocorrência de anticorpos anti-Neospora caninum, antiToxoplasma gondii e anti-Leishmania chagasi em soro de cães do Estado do Pará, Amazônia, Brasil. Parasitology Research, Berlin, v. 107, n. 2, p. 453-457, 2010.

ZACHARY, J. F. Sistema nervoso. In: McGAVIN, M. D.; ZACHARY, J. F. Bases da patologia em veterinária. Tradução de Renata Scavone de Oliveira et al. 5. ed. Rio de Janeiro: Mosby Elsevier, 2013. p. 774-873. 